\title{
49 Opslag van verbandmiddelen
}

\section{Houdbaarheid en opslag}

De houdbaarheid van pleisters op rubberharsbasis (bijvoorbeeld Leukotape, Elastoplast) is niet onbeperkt, aangezien de kleefmassa voor ongeveer twee derde uit substanties bestaat die onderhevig zijn aan natuurlijke veroudering. Als ze bij kamertemperatuur, droog en beschermd tegen licht worden bewaard, behouden ze hun kleefkracht jarenlang en zijn ze tot de laatste centimeter te gebruiken.

Door opslag bij te lage temperaturen wordt de vloeibaarheid aangetast. Het verband zal dan ongeschikt zijn voor gebruik vanwege de te geringe kleefkracht. Dit proces is echter omkeerbaar, dat wil zeggen dat bij verwarming bijvoorbeeld door de huid - het verband zijn volledige kleefkracht weer terugkrijgt.

\section{Te hoge temperaturen vermijden}

Bij opslag bij te hoge temperaturen gedurende een langere periode (bijvoorbeeld tijdens de zomer in de auto, of in de buurt van de verwarming) gaat de kleefkracht onomkeerbaar verloren. Dit proces is definitief omdat het ongemengde rubber al bij circa $60-70^{\circ} \mathrm{C}$ wordt gedenatureerd. Op die manier verliest de kleefmassa zijn innerlijke vastheid (cohesie). Dit geldt ook voor de cohesieve laag van verband (rubber; bijvoorbeeld Gazofix) en voor latexschuim (Leukotape Foam). De oververhitte kleefmassa wordt vettig, dik vloeibaar en verliest zijn kleefkracht. Bij hoge temperaturen, bijvoorbeeld in tropische gebieden, wordt daarom aanbevolen tapemateriaal in de koelkast te bewaren en het in een thermotas of ijsbox te vervoeren.

\section{Straling}

De ultraviolette straling van het zonlicht en vooral ook de intensieve uv-straling van de hoogtezon hebben, voor zover ze rechtstreeks en gedurende langere tijd op de pleistermassa kunnen inwerken, hetzelfde denaturerende effect op rubber als te hoge temperaturen. Cohesief verband verliest zijn kleefvermogen, latexschuim wordt brokkelig. 